\title{
SOPHE Corner
}

\section{Mary Cheryl B. Nacionales, MPH, CHES}

\author{
Health Education and Promotion Manager \\ Asian Americans for Community Involvement
}

The "SOPHE Corner" is a regular column that offers readers an opportunity to learn about the Society for Public Health Education (SOPHE) nationally and its California chapters as well as its on-going activities. This inaugural column is dedicated to providing an overview of SOPHE.

\section{INTRODUCTION}

Society for Public Health Education (SOPHE) is a non-profit professional organization founded in 1950 to promote the health of all people by: stimulating research on the theory and practice of health education; supporting high quality performance standards for the practice of health education and health promotion; advocating for policy and legislation affecting health education and health promotion; and developing and promoting standards for professional preparation of health education professionals. SOPHE is the only professional organization devoted exclusively to public health education and health promotion.

At the national level, SOPHE's membership comprises more than 2,200 individuals with formal training and/or an interest in health education and health promotion throughout the United States and 25 international countries. Members work in schools, universities, medical/managed care settings, corporations, voluntary health agencies, international organizations, and federal, state and local government. There are currently 22 SOPHE chapters covering 31 states and three chapters under development. In the California there are three SOPHE chapters, Northern California, San Diego County, and Southern California.

\section{CHAPTER BACKGROUND}

\section{Northern California}

Originating in 1952 as the San Francisco Bay Area Chapter, NCSOPHE became known as the Northern California Chapter ten years later.

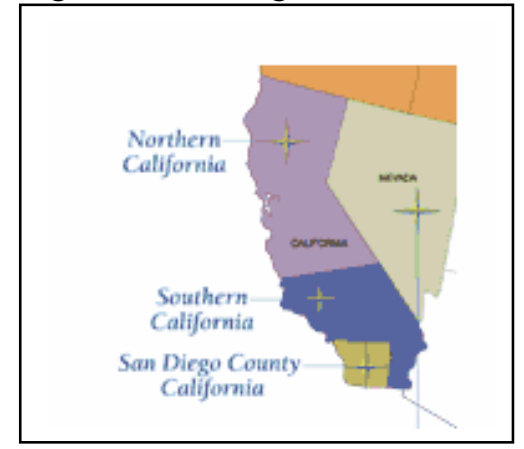
NCSOPHE was the first and one of the largest chapters with a membership of over 200 members. The need for a professional organization arose in the early 1950's as health educators were becoming recognized as members of the public health team. National SOPHE, and subsequently NCSOPHE, were developed to meet this need as they worked to promote ethics and standards within the profession as well as to encourage communication among health educators.

\section{San Diego County}

The San Diego County Chapter of SOPHE was established in 1988 to promote the goals of the Society, to provide continuing education and professional development, and to increase career opportunities for local health education professionals. San Diego SOPHE currently has over one hundred members who represent a variety of health professions and health organizations in San Diego County. Its mission is to promote, encourage and contribute to the advancement of the health of all people through education.

\section{Southern California}

The Southern California Chapter of SOPHE has nearly 100 members serving health education professionals as far north as San Luis Obispo County to California's southern border in Imperial County. 


\section{FALL 2002 AND SPRING 2003 HIGHLIGHTS}

National

SOPHE's International and Cross-Cultural Health Special Interest Group (ICCH-SIG) and SOPHE Ambassadors to the United Nations collaborated with the California State University, Chico to produce SOPHE's first Global Health Disparities CD-ROM. SOPHE is currently collaborating with CSU, Chico and a global health consortium to produce the Mexican-USA Border Health CD-ROM, which is scheduled to be released at the SOPHE Mid-Year Conference in Las Cruces, NM, June 18, 2003. These joint venture further the goals of SOPHE's 2002-2005 Strategic Plan in three key areas:

$>$ promote the use of health education to eliminate health disparities;

$>$ expand SOPHE's international presence and involvement; and

$>$ support and enhance the professional preparation and training of health educators and public health professionals.

Northern California

In April, NCSOPHE will sponsor a professional development workshop on Ethics and Health Education in San Jose.

San Diego County

San Diego SOPHE will be sponsoring the following upcoming events:

$>$ March 25, 2003 Speed Networking -- social event for members

> April 22, 2003 Winning Strategies to Get That Job -- student event held at

San Diego State University

\section{CONTACT INFORMATION}

\begin{tabular}{|l|l|l|l|}
\hline \multicolumn{1}{|c|}{ SOPHE } & \multicolumn{1}{|c|}{ ADDRESS } & \multicolumn{1}{c|}{$\begin{array}{c}\text { PHONE } \\
\text { FAX }\end{array}$} & \multicolumn{1}{c|}{$\begin{array}{c}\text { EMAIL } \\
\text { WEBSITE }\end{array}$} \\
\hline National Office & $\begin{array}{l}\text { 750 First St. NE, Suite 910 } \\
\text { Washington, DC 20002-4242 }\end{array}$ & $\begin{array}{l}\text { (202) 408-9804 } \\
(202) \text { 408-9815 }\end{array}$ & $\begin{array}{l}\text { info@,sophe.org } \\
\text { www.sophe.org }\end{array}$ \\
\hline $\begin{array}{l}\text { Northern } \\
\text { California }\end{array}$ & $\begin{array}{l}\text { 1230 Market Street -- Box 245 } \\
\text { San Francisco, CA 94102-4801 }\end{array}$ & N/A & $\begin{array}{l}\text { ncsophe@,ncsophe.org } \\
\text { www.ncsophe.org }\end{array}$ \\
\hline San Diego County & $\begin{array}{l}\text { P. O. Box 83315 } \\
\text { San Diego, CA 92138-3315 }\end{array}$ & $\begin{array}{l}\text { (858) 642-0306 } \\
\text { (858) 642-0306 }\end{array}$ & $\begin{array}{l}\text { info@,sdsophe.org } \\
\text { www.sdsophe.org }\end{array}$ \\
\hline $\begin{array}{l}\text { Southern } \\
\text { California }\end{array}$ & $\begin{array}{l}\text { P. O. Box 227081 } \\
\text { Los Angeles, CA 90022 }\end{array}$ & N/A & www.socalsophe.org \\
\hline
\end{tabular}

